\title{
Tanısız Lokal Organize Pnömonilerin Akciğer Rezeksiyonları İçindeki Oranı Nedir?
}

\section{What is The Proportion of Local Organizing Pneumonia in Lung Resection?}

\author{
Serda Kanbur Metin ${ }^{1 *}$ \\ Gögüs Cerrahisi Kliniği, İstanbul. \\ e-mail: serdakanbur@gmail.com \\ ORCID: 0000-0003-3983-9420 \\ *Sorumlu yazar/ Corresponding Author: Serda Kanbur Metin \\ Gönderim Tarihi / Received: 09.08.2020 \\ Kabul Tarihi / Accepted: 26.10.2020 \\ DOI: $10.34087 /$ cbusbed.778425
}

${ }^{1}$ Sağlık Bilimleri Üniversitesi, Süreyyapaşa Göğüs Hastalıkları ve Göğüs Cerrahisi Eğitim Araştırma Hastanesi,

\begin{abstract}
Öz
Giriș ve Amaç: Literatürde Lokal Organize Pnömoni (LOP) ve Lokal Bronşiolitis Obliterans Organize Pnömoni (BOOP) olarak adlandırılan, medikal tedaviye yanıt vermeyen, kesin tanı konulamayan akciğer patolojileri cerrahiye gidebilmektedir. Ülkemizde son yıllarda artan tarama yöntemleri nedeniyle tüberküloz kadar sık olmasa da giderek artan sıklıkta maligniteyle karışan, benign akciğer patolojileri içinde yerini almaktadır. Literatürde nadir olarak saptandığı belirtilmekte ve çok az sayıda makalede küçük vaka serilerinde bahsedilmektedir..

Gereç ve Yöntemler: Kliniğimizde Ocak 2013- Aralık 2019 arasında toplam 3795 hastaya akciğerde kitle nedeniyle rezeksiyon yapıldı. Bu hastaların 708'ine Wedge rezeksiyon, 2886'sina ise anatomik rezeksiyon yapıldı. Final patolojisi lokal organize pnömoni (LOP) olarak raporlanan 78 hasta incelendi. Bütün hastalar operasyon öncesi anamnez, fizik muayene, yaş, cinsiyet, sigara kullanımı, Toraks BT, PET-BT, bronkoskopi ve SFT ile değerlendirildi. Bulgular: Final patolojisi LOP olarak raporlanan hastalara cerrahi rezeksiyon olarak, videotorakoskopik veya torakotomi ile wedge $(n=49 \% 63)$ rezeksiyon ve lobektomi $(n=29 \% 37)$ uygulanmıştı. Bu hastaların hiçbirinde operasyon öncesi kesin tanısı yoktu. Hastaların yaşları 42 ile 78 (ort.52) arasındaydı. Hastalarda en sık görülen semptom öksürükdü ( $\mathrm{n}=71 \% 91)$. Hastaların \%91'inde $(\mathrm{n}=71) 10$ paket/yılı aşkın sigara anamnezi mevcuttu. Ek hastalık olarak kronik obstriktif akciğer hastalığı en çok eşlik eden hastalıktı $(n=54 \% 69)$. Hastaların PET-BT'sinde kitlenin SUV tutulumları 2,8 ile 11,7 (ort.6,7) arasında değişmekteydi. Ortalama lezyon boyutu 4,1 $(2,8$ ila 7,3) idi. Hastaların hiçbirine postoperatif LOP olması nedeniyle antibiyoterapi ve kortikosteroid tedavisi uygulanmadı. Hiçbir hastada nüks saptanmadı. Ortalama takip süresi 49 aydı.

Sonuç: Tanı konulamayan, takiplerde gerilemeyen, sigara anamnezi, hemoptizisi ve radyolojik olarak malignite şüphesi olanlarda cerrahiden kaçınmamak gerekir.
\end{abstract}

Anahtar kelimeler: Akciğer kanser cerrahisi, Organize pnömoni, Pulmoner kitle.

\section{Abstract}

Objective: Lung pathologies, which are called Local Organizing Pneumonia (LOP) and Local Bronchiolitis Obliterans with Organizing Pneumonia (BOOP) in the literature, cannot be precisely diagnosed can undergo operation. These have become increasingly common in benign lung pathologies. Studies have rarely detected them and very few articles mention small case series.

Materials and Methods: Between January 2013 and December 2019, a total of 3795 patients underwent resection in our clinic due to a lung mass. Of these patients, 708 underwent wedge resection while 2886 anatomical resection. A total of 78 patients with final pathology reported as Local Organizing Pneumonia (LOP) were evaluated. All patients were preoperatively evaluated with medical history, physical examination, age, gender, smoking, thorax CT, PETCT, bronchoscopy and PFT. 
Results: The patients with final pathology reported as LOP underwent wedge with videothoracoscopic or thoracotomy $(n=49,63 \%)$ resection and lobectomy $(n=29,37 \%)$. The most common symptom in the patients was coughing $(n=71$, $91 \%)$. This patients had of $91 \%(\mathrm{n}=71)$ a history of smoking over 10 packs/year. Chronic obstructive pulmonary disease was the most common concomitant disease $(n=54,69 \%)$. SUV involvement of the mass ranged from 2.8 to 11.7. The mean lesion size was 4.1(2.8 to 7.3). The mean follow-up period was 49 months.

Conclusion: Because of the presence of organizing pneumonia adjacent to malignant neoplasms, solitary nodules should always be considered carefully. Surgery should not be avoided in patients in whom the disease cannot be diagnosed, does not regress in follow-up, who have a history of smoking, hemoptysis and radiologically suspected malignancy.

Keywords: Lung cancer surgery, Organizing pneumonia, Pulmonary mass.

\section{Giriş}

Bronşiyolitis obliterans-organize pnömoni (BOOP) iyi tanımlanmış patolojik ve klinik tanıdır. Patolojik incelemede karakteristik olarak küçük hava yollarının lümenini dolduran granülasyon dokusu tıkaçları ve alveollerde interstisyel inflamasyon mevcuttur [1,2]. Klasik klinik tabloda non-prodüktif öksürük, ateş, nefes darlığı ve halsizlik görülür $[1,3,4]$. Olguların çoğu idiyopatik olmasına rağmen, BOOP çeşitli bakteriyel enfeksiyonlar, romatolojik veya bağ dokusu bozuklukları, immün yetmezlik, viral enfeksiyonlar, organ (kemik iliği, akciğer ve böbrek) nakli, radyasyon ve ilaç toksisitesi ve çevresel maruziyet kaynaklı da görülebilir [1,2]. Hastalarda gaz değişim anomalileri olması ve tedavi yaklaşımları diğer interstisyel akciğer hastalıklarından farklı olduğu için tanı konulması önemlidir. Radyolojik incelemelerde genelde bileteral, yaygın ve düzensiz infiltratif görünümdedir. Bilgisayarl tomografide daha çok subplevral konsolide alanlarda buzlu cam görünümleri, hava bronkogramları ve/veya bronşial dilatasyonlar görülmektedir. Ancak çok daha nadir olarak soliter veya multıple nodüller akciğer kitleleri şeklinde de görülebilmektedir. Bu yüzden fokal BOOP'lar lokalize organize pnömoni (LOP) olarak tanımlanmaktadır $[5,6]$. LOP yani fokal yerleşimli BOOP daha nadir olarak karşımıza çıkan bir klinik tablodur. Literatürde LOP kısa vaka serileri veya olgu sunumları şeklinde yer almaktadır. Tanısında bronkoalveolar lavaj veya transbronşial iğne biyopsisi kullanılsa da altın standart tanı yöntemi cerrahi biyopsidir [7]. Çoğu hasta da radyolojik olarak saptanan LOP [18F]-2-fluoro-2-deoxy-D-glucose positron emission (FDG) tomography (PET-BT) yüksek SUV (standardized uptake values) değerleri yüzünden malignite ile karışabilmekte ve cerrahi rezeksiyona kadar gitmektedir.

$\mathrm{Bu}$ çalışmada preop kesin tanı alamamış veya medikal tedavi ile gerilememiş cerrahi ile tanı konulan nadir görülen LOP vakalarını inceledik.

\section{Materyal ve Metot}

Kliniğimizde Ocak 2013- Aralık 2019 arasında toplam 3795 hastaya akciğerde kitle nedeniyle rezeksiyon yapıldı. $\mathrm{Bu}$ hastalarin 708 'ine Wedge rezeksiyon, 2886'sina ise anatomik rezeksiyon yapıldı. Final patolojisi lokal organize pnömoni (LOP) olarak raporlanan 78 hasta incelendi. Bütün hastalar operasyon öncesi anamnez, fizik muayene, yaş, cinsiyet, sigara kullanımı, Toraks BT, PET-BT, bronkoskopi ve SFT ile değerlendirildi. Klinik olarak enfeksiyon düşündüren bulguları saptanan hastalarda, operasyon öncesi gögüs hastalıkları uzmanı tarafından antibiyoterapi ile tedavi edilmişti. Hastaların hepsinde operasyon sırasında kitle örneklenerek frozen section ile değerlendirildi. Postoperatif mortalite ve morbidite incelendi. Operasyon sonrası ilk 30 günde kaydedilen komlikasyonlar ile ölüm operatif morbidite ve mortalite olarak değerlendirildi. BT özellikleri ve FDG tutulumları kaydedildi. Tüm patoloji materyalleri haemotoksylin eozin ile boyanarak incelendi. Gerekli durumlarda ileri boyama teknikleri yapıld1. Hastaların operasyon sonrası rutin kontrolleri 1.,3., 6., ve 12. aylarda yapıldı. Takipleri ek patolojik problemi olmayan hastalarda 1. yilın sonunda sonlandırıldı. Tüm hastalardan ameliyat öncesi onam formu alındı. Çalışma Helsinki Beyannamesindeki prensiplere uygun olarak yapıldı.

\section{Bulgular ve Tartışma}

Final patolojisi LOP $(n=78)$ olarak raporlanan hastalara cerrahi rezeksiyon olarak, videotorakoskopik veya torakotomi ile wedge $(n=49 \% 63)$ rezeksiyon ve lobektomi $(n=29 \% 37)$ uygulanmıştı. Oniki hasta beraberinde farklı patolojiler içerdiği için (bronşektazi, malin tümör ve pulmoner sekestrasyon) çalışmaya alınmadı. Sadece $7(\% 8,9)$ hastaya $1 \mathrm{~cm}$ üzerinde büyümüş ve yüksek FDG tutulumu nedeniyle mediastinoskopi yapılmıştı. Bu hastaların hiçbirinde operasyon öncesi kesin tanısı yoktu ve klinik, radyolojik olarak malignite yönünden şüpheliydi. Hastaların 56's1 erkek, 22'si ise kadındı ve yaşları 42 ile 78 (ort.52) arasındaydı. Hastalarda en s1k görülen semptom öksürükdü $(n=71 \% 91)$. Diğer semptomlar ise nefes darlığı, göğüs ağrısı, halsizlik ve ateş idi. Hastaların \%91'inde $(\mathrm{n}=71) 10$ paket/yılı aşkın sigara anamnezi mevcuttu. Ek hastalık olarak kronik obstriktif akciğer hastalığı $(\mathrm{KOAH})$ en çok eşlik eden hastalıktı $(\mathrm{n}=54$ $\% 69$ ). Hastaların sadece 2 'sinde daha önce den geçirilmiş akciğer dışı malignite ve kemoterapi (mesane kanseri ve nazofarenks kanseri) öyküsü mevcuttu. Olguların 48'inde $(\% 61,5)$ daha önce geçirilmiş rekürren pulmoner enfeksiyon hikayesi mevcuttu. Tüm LOP tanısı alan hastaların 52'si $(\% 66,6)$ semptomatik iken 26's1 $(\% 33,3)$ asemptomatikti ve başka nedenlerle çekilmiş toraks BT 'de kitle saptanmıştı. Operasyondan önce semptomatik olan 52 hastaya da pulmoner enfeksiyon düşünülüp antibiyoterapi verilmiş ve rezolüsyon gelişmediği için 
ileri tanısal tetkik yapılmıştı. Bu hastaların aynı zamanda nefes darlığı da $(n=12)$ olanlarına göğüs hastalıkları kliniğince kortikosteroid tedavisi de yapılmıştı. Biyokimyasal parametleri incelendiğinde sadece 2 hasta

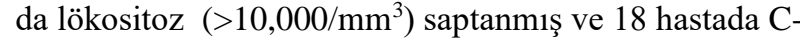
reaktif protein seviyeleri $(>6 \mathrm{mg} / \mathrm{L})$ yüksek bulunmuştu. Hastaların PET-BT'sinde kitlenin SUV tutulumları 2,8 ile 11,7 (ort.6,7) arasında değişmekteydi. Ortalama lezyon boyutu 4,1 (2,8 ila 7,3) idi (Resim 1).

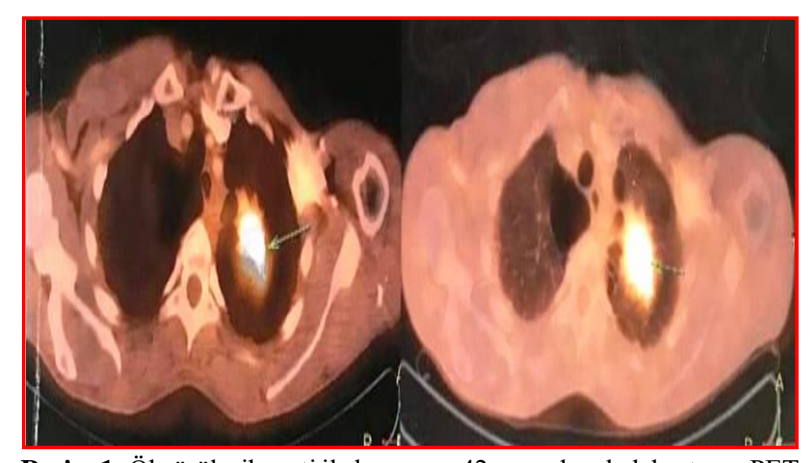

Resim 1: Öksürük şikayeti ile başvuran 42 yaşında erkek hastanın PET BT'sinde sol üst lob yerleşimli, SUV tutulumu 8.2 olan kitle. Wedge rezeksiyon sonucu patoloji LOP ile uyumlu.

$\mathrm{Bu}$ hastaların hepsine operasyon öncesi bronkoskopi yapılmış ancak 12'sine transtorasik iğne aspirasyon biyopsisi yapılmış ve tanı konulamamıştı. Hastaların akciğer lezyonlarının yerleşim yeri olarak dağılımı ise; sağ üst lobda $35(\% 44,8)$, orta lobda $3(\% 3,8)$, sağ alt lobda $13(\% 16,6)$ sol üst lobda $15(\% 19,2)$, sol alt lobda $12(\% 15,3)$ idi (Tablo1). Ortalama lezyon boyutu 4,1 (2,8 ila 7,3$)$ idi. Bilateral pulmoner lezyon hiçbir hasta da yoktu. Wedge rezeksiyon yapılan hastaların hepsinde kitlenin tamamı wedge rezeksiyon materyelinin içinde idi. Wedge rezeksiyon ile tamamı çıkarılamayan, makroskopik görünümü malignite şüpheli olan, frozenda kitlenin tamının örneklenemediği, tekrarlayan hemoptizileri olan ve bronş invazyonu gösteren kitlelerin hepsine anatomik lobektomi yapıldı. Hiçbir hastaya pnömonektomi gerekmedi. Rezeksiyon patolojileri 2 farklı patolog tarafindan değerlendirildi (Resim 2).

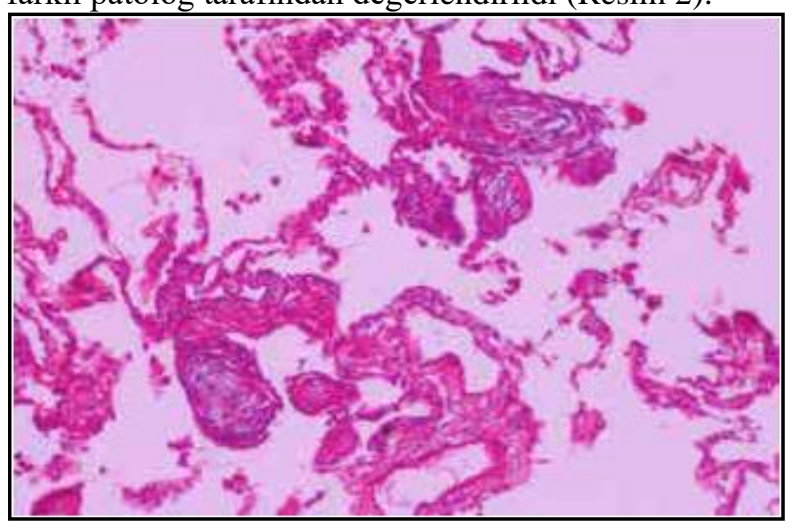

Resim 2. Tipik organize pnömoninin histpatolojik görünümü (H\&E x 10).

Hastaların 31'inde yoğun plevral yapışıklık mevcuttu. Hiçbir hastada postop erken dönem mortalite yaşanmadı. Morbidite olarak 11 (\%14,1) hastada uzamış hava kaçağı (5 günü aşan), 1'nde $(\% 1,2)$ ise postop hemoraji nedeniyle revizyon dişında hiçbir komplikayon görülmedi. Hastaların hiçbirine postoperatif LOP olması nedeniyle antibiyoterapi ve kortikosteroid tedavisi uygulanmadı. Hiçbir hastada nüks saptanmadı. Ortalama takip süresi 49 aydı. Tüm hastaların klinik ve radyolojik özellikleri Tablo 1'de gösterilmiştir.

Tablo 1. LOP tanısı alan Hastaların klinik ve radyolojik özellikleri

\begin{tabular}{|l|l|l|}
\hline Değişken & $\begin{array}{l}\text { Soliter } \\
\text { Nodül }\end{array}$ & Kitle \\
\hline Hasta sayısı & 49 & 29 \\
\hline Erkek/Kadın & $52 / 19$ & $26 / 3$ \\
\hline Yaş (ortalama yıl/aralık) & $\begin{array}{l}52(46- \\
78)\end{array}$ & $\begin{array}{l}56(49- \\
78)\end{array}$ \\
\hline Sigara Hikayesi & 29 & 42 \\
\hline Semptomatik Hastalık & 25 & 27 \\
\hline Lökositoz & 0 & 2 \\
\hline Yüksek CRP & 2 & 16 \\
\hline $\begin{array}{l}\text { Lokasyon } \\
\text { Sağ üst lob }\end{array}$ & 23 & 12 \\
$\begin{array}{l}\text { Sağ orta lob } \\
\text { Sağ alt lob }\end{array}$ & 2 & 1 \\
$\begin{array}{l}\text { Sol üst lob } \\
\text { Sol alt lob }\end{array}$ & 8 & 5 \\
\hline $\begin{array}{l}\text { Lezyon Boyutu (ortalama, } \\
\text { mm) }\end{array}$ & 11 & 4 \\
\hline $\begin{array}{l}\text { Büyümüş Mediastinal Lenf } \\
\text { Nodu }\end{array}$ & 19.5 & 7 \\
\hline Rezeksiyon Tipi & 1 & 6 \\
\hline Cerrahi mortalite & Wedge & Lobektom \\
\hline $\begin{array}{l}\text { Cerrahi morbidite } \\
\text { Uzamış hava kaçağ1 }(>5 \\
\text { gün) }\end{array}$ & 3 & 0 \\
\hline Hemoraji & 0 & 8 \\
\hline
\end{tabular}

Nadir görülmesine rağmen, LOP göğüs cerrahları için primer veya metastatik malign akciğer tümörlerinden ayrılması zor olduğu için ilginç vakalardır. İlk olarak 1989 yılında Cordier ve ark. tarafindan BOOP'tan ayrı bir form olarak tanımlanmıştır [8]. LOP'un tanısını koymak BOOP'da olduğu gibi klinik ve radyolojik olarak koymak mümkün olmamaktadır. Literatürde LOP, BOOP'un fokal varyantı olarak nodüler BOOP, yuvarlak BOOP veya soliter BOOP gibi tanımlarla adlandırılmaktadır. Tüm bu isimler aslında LOP'un radyolojik özelliklerini yansıtan tanımlardır. Tüm bu fokal radyolojik tanımlar BOOP'tan (klasik veya tipik) pulmoner parankimde daha sık görülen interstisyel pnömonide radyolojik olarak ayrım yapabilmek amacıyla yapılmıştır. LOP'un kesin insidansı bilinmemekle birlikte literatürdeki vaka serileri de çok azdır [7,9]. Pulmoner rezeksiyona neden olmuş vaka serilerinin kesin sayısı da bilinmemektedir. BOOP genelde spesifik olmayan inflamatuar süreç olarak tanımlanmaktadır. Etyolojisi kesin olarak bilinmemekle birlikte, ilaçlar, radyoterapi ve bakteriyal enfeksiyonların yol açtığ 1 rezolüsyon olmayan pnömoni olarak tanımlanmaktadır. İnflamasyon boyunca 
antibiyoterapiye rağmen alveol içerisinde fibrinöz yapıda exuda birikmesiyle karakterizedir [1]. LOP akciğerde rezolüsyona uğramayan fokal alanlar olarak görülmektedir. Bu hipotez bu seride de \%61,5 oranında hastamızda daha önce geçirilmiş tekrarlayan enfeksiyon anamnezini desteklemektedir. LOP'un bu enfeksiyon doğası yine bu çalışmadaki hastalarımızda \%69 oranında saptanan KOAH'ı da açıklamaktadır. KOAH hastalarında da peryodik pulmoner enfeksiyon sıklığı ve bakteri kolonizasyonu LOP'a neden olabilir. $\mathrm{Bu}$ serideki hastalarda da diğer serilerdeki hastalara benzer karakterde özellikler görmekteyiz [7,10]. LOP genellikle asemptomatik veya hafif semptomatik olarak karşımıza çıkmaktadır. KOAH ve sigara içen erkeklerde daha fazla ortaya çıkmaktadır. Bu seride de bunu saptadık. Oysa ki BOOP genellikle semptomatikdir ve sigara ile ilişkisi bulunmazken rekstiriktif ventilasyon defekti olarak karşımıza çıkmaktadır [1,2]. LOP BT'de düzensiz kontürlü, yuvarlak bazen oval şekilde, soliter veya multıple nodül yada kitle olarak karşımıza çıkmaktadır $[11,12,13]$. Bazı vakalarda hava bronkogramlı satellit nodüller, plevral çekinti ve buzlu cam görünümünde de heterojenite gösterebilmektedir. Bu özellikleri itibarıla diğer akciğer patolojilerinden ve metastatik akciğer hastalıklarından da ayırımı güçlük göstermektedir. Literatürde de sınırlı vaka serilerinde sadece radyolojik görünüm ve PET-BT'deki yüksek SUV değerleri nedeniyle maligniteden ayrımının yapılamayacağı, histopatolojik incelemenin kesin tanı için mutlaka elzem olduğu belirtilmiştir [14]. Maldonado ve arkadaşlarının yaptı̆̆ LOP'un kesin tanısı için cerrahi rezeksiyonun yeterli olacağ bildirilmiştir [15]. Transbronşial iğne biyopsisi veya BT eşliğinde yapılan perkütan biyopsilerin tanıda yetersiz kaldığı kesin tanının ancak cerrahi olarak konulabileceği birçok yayında belirtilmektedir [16]. Yılmaz ve arkadaşlarının yaptığı çalışmada da bir çok hastanın kesin tan için cerrahi rezeksiyonun gerektiği belirtilmiştir [17]. Geçirilmiş viral enfeksiyon LOP'un etyolojisinde yer aldığı için Covid-19 enfeksiyonu geçiren hastaların uzun takiplerinde de bu kalıcı lokal lezyonların oluşabileceğini düşünmekteyiz.

\section{Sonuç}

Sonuç olarak LOP klinik ve radyolojik olarak tipik BOOP'dan farklıdır. Nodül veya kitle olarak karşımıza çıkan LOP'un primer veya metastatik akciğer tümörlerinden ayırmak zordur. Pek çok hastada yüksek SUV tutulumu, nonspesifik tedaviye radyolojik yanıtın olmaması, non-invaziv yöntemlerin tanı değerinin az olması ve sigara anamnezi olası malignite ekartasyonu için bizi cerrahi rezeksiyona yönlendirmektedir. Cerrahi rezeksiyon hem teşhis ve hem de tedavi açısından gerekli olmaktadır. Ancak yine de benign natürü nedeni ile daha büyük pulmoner rezeksiyonlardan kaçınılması gerekmektedir.

\section{Referanslar}

1. Cordier, J.F, Organizing pneumonia. Thorax, 2000, 55, 318-28.

2. Epler, G.R, Bronchiolitis obliterans organizing pneumonia, Archives of Internal Medicine, 2001,161, 158-64.
3. Cordier, J.F, Cryptogenic organizing pneumomia, Clinical Chest Medicine, 2004, 25, 727-38

4.Özdilekcan, C, Erișkinlerde Kronik Öksürük: Etyolojik, Tanısal Ve Tedavi İle İlgili Yaklaşımlar, Celal Bayar University Journal of Science, 2018, 5(2), 47-51.

5. Ujita, M, Renzoni, E.A ve ark, Organizing pneumonia: perilobular pattern at thinsection CT, Radiology, 2004, 232, 757-61.

6. Kim, S.J, Lee, K.S ve ark, Reversed halo sign on high-resolution CT of cryptogenic organizing pneumonia: diagnostic implications, AJR American Journal of Roentgenology, 2003, 180, 1251-4.

7. Melloni, G, Cremona, G, ve ark, Localized Organizing Pneumonia: Report of 21 Cases, Annals of Thoracic Surgery, 2007, 83, 1946 -51.

8. Cordier, J.F, Loire, R, Brune, J, Idiopathic bronchiolitis obliterans organizing pneumonia: definition of characteristic clinical profiles in a series of 16 patients, Chest, 1989, 96, 999-1004.

9. Zhao, F, Yanc, S, ve ark, CT features of focal organizing pneumonia: An analysis of consecutivehistopathologically confirmed 45 cases, European Journal of Radiology, 2014, 73-78.

10. Watanabe, K, Harada, ve ark, Organizing pneumonia presenting as solitary nodular shadow on a chest radiograph, Respiration 2003, 70, 507-14

11. Kohno, N, Ikezoe, J ve ark, Focal organizing pneumonia: CT appearance, Radiology, 1993, 189, 119 -23.

12. Akira, M, Yamamoto, S, Sakatani, M, Bronchiolitis obliterans organizing pneumonia manifesting as multiple large nodules or masses, AJR American Journal of Roentgenoly, 1998,170, 291-5.

13. Lohr, R.H, Boland, B.J ve ark, Organizing pneumonia, Features and prognosis of cryptogenic, secondary, and focal variants, Archives of Internal Medicine, 1997, 157, 1323-9.

14. Erdoğan, Y, Özyürek, B.A ve ark, The Evaluation of FDG PET/CT Scan Findings in Patients with Organizing Pneumonia Mimicking Lung Cancer, Molecular Imaging and Radionuclide Therapy, 2015, 24(2), 60-65.

15. Maldonado, F, Daniels, C.E ve ark, Focal organizing pneumonia on surgical lung biopsy: Causes, clinicoradiologic features, and outcomes, Chest, 2007, 132, 1579-1583.

16. Yu, G, Ji, H ve ark, Surgical management of organizing pneumonia: a retrospective study of 24 cases in a single Centre, Journal of Cardiothoracic Surgery, 2019, 14, 122, 14-28.

17. Yılmaz, S, Akıncı Özyürek, B ve ark, Retrospective evaluation of patients with organizing pneumonia: is cryptogenic organizing pneumonia different from secondary organizing pneumonia? Tuberküloz Toraks, 2017, 65, 1-8.

http://edergi.cbu.edu.tr/ojs/index.php/cbusbed isimli yazarın CBU-SBED başlıklı eseri bu Creative Commons Alıntı-Gayriticari4.0 Uluslararası Lisansı ile lisanslanmıştır.

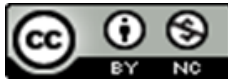

